\title{
Gastrointestinal involvement in Chagas disease
}

\section{Claudio R. Bilder ${ }^{1 *}$ and Juan C. Goin ${ }^{2}$}

${ }^{1}$ Laboratorio de Neurogastroenterología, Fundación Favaloro-Hospital Universitario; ${ }^{2}$ Laboratorio de Farmacología Molecular, Centro de Estudios Farmacológicos y Botánicos (CEFYBO-CONICET-UBA), II Cátedra de Farmacología, Facultad de Medicina, Universidad de Buenos Aires. Argentina

\section{RESUMEN}

La acalasia y el megacolon son las segundas manifestaciones más comunes de la enfermedad de Chagas (ECh), crónica en áreas endémicas de América Central y del Sur. Luego de veinte o más años desde la primoinfección, aproximadamente un tercio de las personas infectadas desarrollan alteraciones cardíacas y / o gastrointestinales típicas de la etapa crónica. Esta fase se caracteriza por daño neuronal mientérico (intrínseco) y autonómico (extrínseco). En pacientes con megaesófago y megacolon puede detectarse una densidad disminuida de células entéricas gliales, así como una pérdida de células intersticiales de Cajal. Estas lesiones afectan los complejos mecanismos neurales, moleculares y celulares que modulan la actividad motora y otras funciones específicas del tracto digestivo. Evidencias sobre la presencia de anticuerpos séricos con capacidad para reconocer epitopes similares tanto en antígenos de Trypanosoma cruzi como del huésped sugirieron que el mimetismo molecular podía desempeñar un papel sustancial en la fisiopatología de la enfermedad de Chagas crónica. En particular, se ha encontrado una alta prevalencia de anticuerpos circulantes contra receptores muscarínicos de acetilcolina M2 (RM2) en pacientes chagásicos con acalasia y megacolon. Estos anticuerpos se unen y activan a los RM2, exhibiendo una actividad semejante a la de los agonistas muscarínicos. Los anticuerpos anti-RM2 pueden incrementar la contracción tónica tanto en el esófago distal como en el colon distal por estimulación directa o bien contrarrestar los efectos relajantes de drogas que incrementan la acumulación de AMPc (p. ej., agonistas betaadrenérgicos). Los efectos bioquímicos y funcionales de estos anticuerpos en el músculo liso esofágico y colónico podrían desempeñar un rol importante en la fisiopatología de la acalasia y el megacolon secundarios a ECh. (NeuroGastroLatam Rev. 2017;1:168-179) Corresponding author: Claudio Bilder, cbilder@ffavaloro.org

Palabras clave: Chagas. Acalasia. Megacolon. Anticuerpos muscarínicos. 


\section{ABSTRACT}

Achalasia and megacolon are the second most common manifestations of chronic Chagas disease $(\mathrm{ChD})$ in endemic areas of Central and South America. Twenty or even more years after the initial infection, approximately one-third of infected people develop cardiac and/ or gastrointestinal abnormalities as typical chronic damages of $\mathrm{ChD}$. The chronic phase of $\mathrm{ChD}$ is characterized by the damage of myenteric (intrinsic) and autonomic (extrinsic) neurons. A decreased density of enteric glial cells can be detected in patients with megaesophagus and megacolon and a loss of interstitial cells of Cajal. These lesions affect the complex mechanisms of neural, molecular, and cellular interactions that modulate the motor activity and other specific functions of the alimentary tract. Evidence for serum antibodies with the ability to recognize similar epitopes in both Trypanosoma cruzi and host antigens suggested that molecular mimicry could play a substantial role in the pathophysiology of chronic ChD. In fact, a high prevalence of circulating antibodies against $\mathrm{M} 2$ acetylcholine muscarinic receptor (M2R) in ChD patients with achalasia and megacolon has been found. These antibodies bind to and activate M2R, exhibiting agonist-like activity. Anti-M2R antibodies can both enhance tonic contraction in lower esophagus and distal colon by direct stimulation and also by counteracting the relaxant effect of drugs that increase cAMP accumulation (i.e. beta-adrenergic agonists). The biochemical and functional effects of these antibodies on esophageal and colon smooth muscle could play an important role in the pathophysiology of achalasia and megacolon secondary to ChD.

Key words: Chagas. Achalasia. Megacolon. Muscarinic antibodies.

\section{CHAGAS DISEASE (ChD): GENERAL ASPECTS}

The American trypanosomiasis ChD still represents a major health problem, particularly in poor and rural populations of Central and South America. ChD has three well-recognized clinical successive phases: (1) the acute infection, (2) an "indetermined" (symptomatically silent) phase, and (3) a chronic phase, typically 20 years or more after the initial infection, during which clinical manifestations appear ${ }^{1}$.

As regard to cardiac abnormalities, their signs and symptoms are the most common expressions of chronic ChD: palpitations, dizziness, chest pain, and even syncope that reflect different arrhythmias, including ventricular tachycardia with sudden death, which is not at all unusual in an otherwĭّ healthy young adult. Signs and symptoms related to arrhythmias could be present for a long period before cardiomegaly or congêstive heart failure appears ${ }^{2}$.

The primary aim of this article is to review the gastrointestinal involvement of chronic ChD, focusing on the most recent molecular advances to better understand the pathophysiological mechanisms of chagasic digestive damage. 
Achalasia and megacolon are the second most common manifestations of chronic ChD. The gastrointestinal involvement results from denervation of the hollow viscera. Usually, esophagus and colon are affected the most; however, the duodenum and the small bowel could also be dilated. Moreover, even in patients with asymptomatic chagasic involvement of the intestine, a significant reduction in submucosal and myenteric ganglionneurons was demonstrated ${ }^{3}$.

Cardinal symptoms include gastric dilatation (gastroparesis), nausea, vomiting, and upper abdominal pain. More frequently, with duodenal and small bowel dilatations: bloating, diarrhea and/or constipation may be part of the picture; in the presence of stasis, it is possible to find signs of bacterial overgrow th ${ }^{4}$.

\section{CHRONIC CHAGASIC ESOPHAGEAL INVOLVEMENT}

Except for the exposure to Trypanosoma cruzi, the clinical history of patients with chagasic achalasia is indistinguishable from that of idiopathic achalasia. The symptoms are dysphagia, feeling, of fullness after eating or drinking small amounts, chest pain, and regurgitation. Weight loss and aspiration with secondary pneumonia are common findings in advanced cases. Chagasic achalasia, in early stages, shows minimal or no esophageal dilatation in contrast barium studies (Fig. 1). Various degrees of esophageal dilatation and retention of barium because of a delayed esophageal emptying could be seen in advanced stages of chagasic achalasia (megaesophagus).

Upper video endoscopy should be regularly performed to rule out obstructive-proliferating

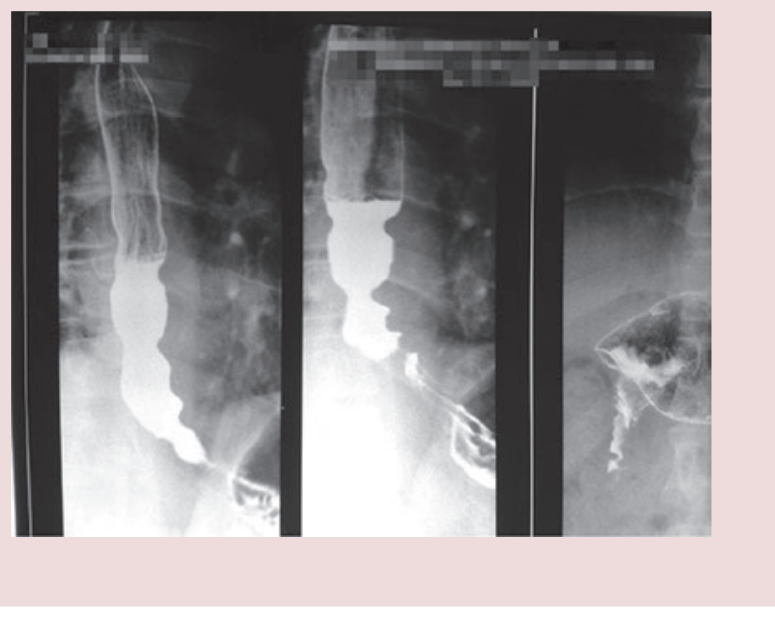

Figure 1. Barium esophagogram of an early stage non-dilated chagasic achalasia.

endoluminal diseases: malignancies and peptic and non-peptic (inflammatory and/or infectious) stenosis. During the chronic phase, the diagnosis of $\mathrm{ChD}$ is based on a history of exposure to the insect vector and a positive serologic test for specific antibodies againste cruzi, generally an enzyme-linked immunosorbent assay (ELISA) and an indirect immunofluorescence test ${ }^{1}$.

\section{ESOPHAGEAL MANOMETRY: DEFINITIONS AND CONTRIBUTIONS}

Achalasia is defined as an esophageal motor disorder characterized by an impaired lowerer esophageal sphincter (LES) relaxation and an aperistaltic smooth muscle esophageal sègment. Conceptually, identical findings have been described in patients with chagasic achalasia $^{5}$. Currently, high-resolution manometry (HRM) is considered the best way of analyzing and quantifying LES relaxation and the peristaltic activity of the esophageal body, which are the crucial functions to assess to establish the diagnosis of achalasia ${ }^{6}$. 
LES relaxation resting pressure is measured by means of the four second-integrated relaxation pressure (4 - IRP), which can be defined as the median LES pressure related to the gastric pressure during the $4 \mathrm{~s}$ of lower LES pressure within a timeframe of $10 \mathrm{~s}$ starting from the moment of upper esophageal sphincter relaxation ${ }^{7}$. In fact, utilizing IRP, achalasia is defined more precisely than with conventional manometry. Moreover, with the criteria coming from the use of HRM and the application of the Chicago Classification, three distinct types of achalasia were described $^{8}$ (Fig. 2A-D). The three types of achalasia are characterized by incomplete LES relaxation; they differ in pressurization patterns and the presence of premature high amplitude contractions in the type III (or spastic achalasia). The type I, or classic achalasia, has poor or absent pressurization, and the type II shows panesophageal pressurization (or bolus compression $)^{9}$. Following this sub classification of achalasia, different studies demonstrate distinct responses after treatment. All evaluations uniformly show that the bèst treatment response was in achalasia type II patients and the worst therapeutic response was obtained among type III achalasia pà tients; this observation includes the different modalities of achalasia treatment ${ }^{10,11}$.

Series of chagasic achalactic patients are cürrently being investigated, presumably, under the Chicago classification criteria, which will be of the salient clinical value to know the distribution of subcategorization of chagașic
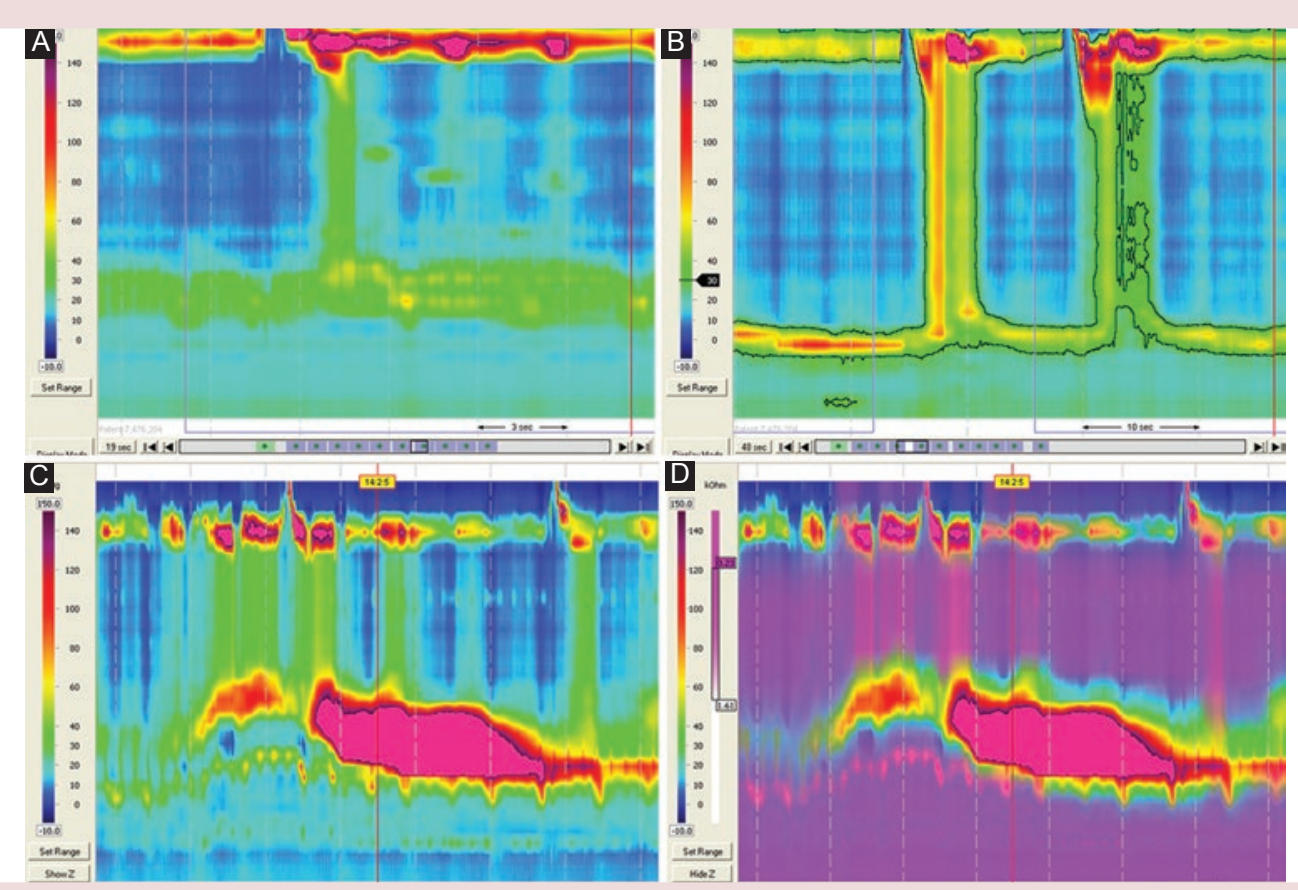

FIgURE 2. (A) Classic achalasia or type I, non-relaxing lower esophageal sphincter (LES), aperistaltic esophageal body with an intraluminal pressure $<30 \mathrm{mmHg}$. High-resolution esophageal manometry (HREM). (B) Achalasia type II, non-relaxing LES, aperistaltic esophageal body with panpressurization or compression with a $30 \mathrm{mmHg}$ isobara (black contour) (HREM). (C) Achalasia type III, non-relaxing LES, aperistaltic esophageal body with high-amplitude premature contractions (spastic achalasia) and "shortening" due to a longitudinal muscle layer contraction (HREM). (D) The same achalasia type III with simultaneous impedance, the purple color indicates fluid retention in the esophageal lumen and in the gastric fundus (high-resolution esophageal/impedance manometry). 
achalasia and to uniformly evaluate their therapeutic responses.

\section{CHRONIC CHAGASIC INTESTINAL INVOLVEMENT}

Chronic chagasic patients with megacolon suffer from infrequent bowel movements (constipation), usually associated with bloating, distention, and colicky abdominal pain. Hypoactive or "distant" bowel sounds are typical physical findings. Constipation could be severe, not infrequently, these patients refer several weeks between every bowel movement. Volvulus, obstruction, and perforation can occur as dramatic complications in chagasic patients with universal or segmental megacolon. An abdominal XR film, a barium enema with air contrast, and a computed tomography abdominal scan, characteristically, show dilated colonic loops with poor or no peristalsis and megarectum (Fig. 3). Video colonoscopy should be performed to rule out malignant diseases and other colonic and extra-colonic causes of gastrointestinal obstructions.

\section{FROM CLASSICAL AND RECENT MORPHOLOGIC STUDIES TO MANOMETRIC EVALUATIONS}

Classical and early morphologic studies relied on either resection specimens or necropsy material from patients undergoing resections for end-stage or advanced chagasic megaviscera. These dilated, atrophic, and "chronically non-peristaltic" hollow viscera iteratively showed the absence of myenteric ganglia and marked fibrosis ${ }^{12}$.

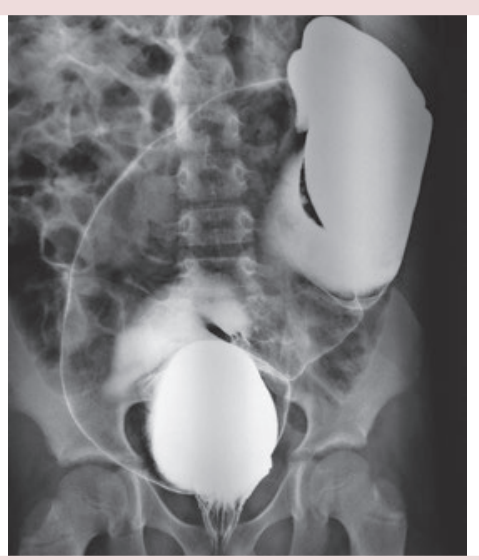

Figure 3. Air-contrast barium enema of a chagasic mega-sigma

The availability of tissue specimens from patients in earlier stages of chagasic megacolön became possible due to the wide adoption laparoscopic surgery and the use of new alagnostic tests ${ }^{13}$.

The enteric nervous system (ENS) is a vâst neural network along the whole alimentary tract, biliary tract, and pancreas. Based on his tochemical and electrophysiological propèrties, the 80-100 million enteric neurons can be classified into functionally distinct subpopulations: intrinsic primary afferent neurons, interneurons, motor neurons, and secretomotor and vasomotor neurons ${ }^{13}$. The ENS has the unique ability to control these fundamental gastrointestinal functions: absortion/secretion, vascular tone, and motor activity; given these important functions of the ENS, its damage results in a variety of digestive disorders.

Modern immunohistochemistry techniques have shown marked abnormalities of the ENS in patients with chagasic megacolon: (a) a decreased number of enteric neurons and enteric glial cells, (b) a mild lymphocytic infiltration of the enteric plexuses ("plexitis"), and (c) a 
loss (but not absence) of interstitial cells of Cajal subtypes, although an increase of the intramuscular subtype has also been found, suggesting a possible compensative mechanism ${ }^{14}$.

These findings could be related to the abnormalities that have been found in chagasic patients with lower basal motility index and wave frequency of the sigmoid colon and rectum compared with normal subjects ${ }^{15}$. In chronic chagasic patients, the propagation of the migrating motor complex is slower and its duration longer than in control individuals, suggesting that neuropathic damage results in alterations of the interdigestive motorcycle controlled by the ENS ${ }^{16}$. As occurs with idiopathic megacolon, colonic manometry could facilitate the identification of chagasic colonic inertia characterized by a poor or absent contractile response to feeding and after a pharmacologic provocative test employing $5 \mathrm{mg}$ of intracolonic bisacodyl (Fig. 4).

A lack of relaxation of the internal anal sphincter and an absence of the rectoanal inhibitory reflex (RAIR) were demonstrated in chronic chagasic patients with megacolon ${ }^{17}$; this finding could be explained by the presence of aganglionosis. However, in some patients, the absence of the RAIR could be the result of megarectum rather than the expression of a true aganglionosis ${ }^{18}$.

\section{ROLE OF THE IMMUNE SYSTEM IN THE PATHOPHYSIOLOGY OF ACHALASIA AND MEGACOLON SECONDARY TO ChD}

Over the past 20 years, several findings suggested the involvement of the immune system in the pathophysiology of achalasia and megacolon secondary to T. cruzi infection. The presence of inflammatory cell infiltrate in the myenteric plexus of the gastrointestinal tract as well as the detection of circulating antibodies against neural and/or smooth muscle structures in the absence of evident infection has been associated with immune activation añd inflammation, both in $\mathrm{ChD}$ patients a⿳َّ̆ T. cruzi-infected rodents. The inflammatờ process is characterized by myositis and ganglionitis, which appear to be more frequentīin organs with mega than those without enlargement and in esophagus compared to colon ${ }^{1920}$. Qualitatively, the inflammatory infiltration muscular and myenteric plexus from esophagus and colon is similar, consisting predominantly of $\mathrm{T}$ lymphocytes (CD3+), few macrophages (CD68+), and rare $\mathrm{B}$ lymphocytes $(\mathrm{CD} 20+)$ regardless of the presence of orgăn enlargement ${ }^{20}$, although other studies have found a predominance of macrophages $(\mathrm{CD} 68+)$ in the myenteric plexus region from patients with megaesophagus ${ }^{21}$ or a predominance of $\mathrm{B}$ lymphocytes in the submucous plexus from patients with megacolon ${ }^{22}$. Quaintitatively, megaorgans appear to exhibit higher numbers of inflammatory cells than those with normal dimensions ${ }^{21}$.

As described above, T. cruzi promotes a strong immune response not only against its own antigens but also against host self-strǚctures. For example, $\mathrm{T}$ cells crossreacting with T. cruzi antigens and nervous tissue can cause peripheral nervous tissue damage when passively transferred to naive animals ${ }^{23,24}$. Selected anti-T. cruzi monoclonal antibodies have been found to recognize host antigens, and cross-reactivity of circulating antibodies from ChD patients between T. cruzi antigens 


\section{A}

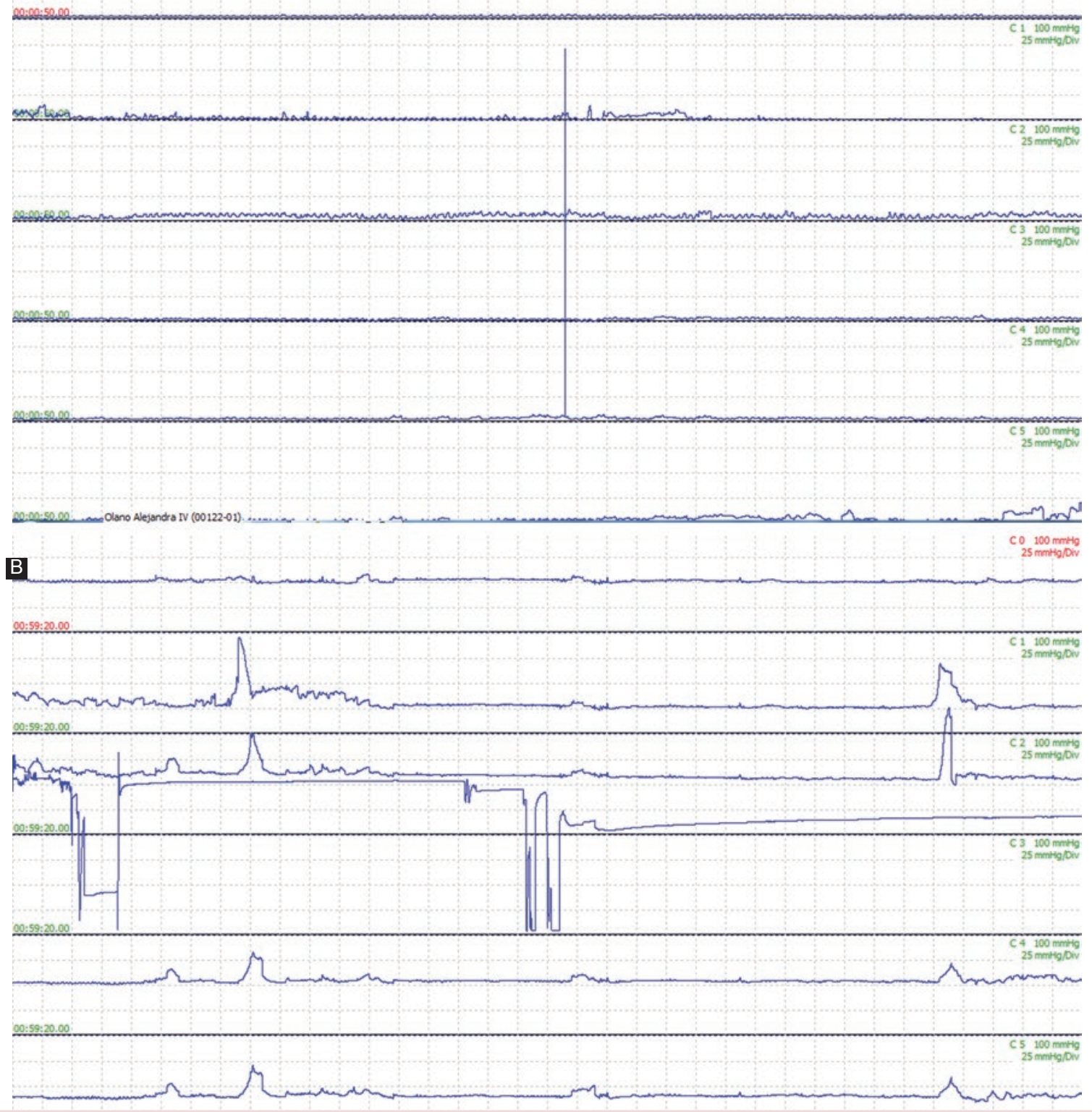

Figure 4. Colonic manometry in a non-chagasic patient with colonic inertia. (A) A 15 min-representative segment of a tracing showing a poor basal colonic contractile activity from the hepatic flexure (upper channel) to the rectum (lower channel). (B) a 15 min-segment of the same tracing where the channel 4 was disconnected to infuse $5 \mathrm{mg}$ bysacodil. Few minutes after the infusion, two successive sequences of $50 \mathrm{mmHg}$ and $<30 \mathrm{mmHg}$ amplitude contractions were obtained. This is a positive test suggesting a colonic functional reserve to respond to some laxative agents.

and host proteins muscular or nervous tissue has also been described ${ }^{25}$.

The finding of both immunocompetent cells and circulating antibodies with the ability to recognize similar epitopes in both $T$. cruzi and host antigens suggested that molecular mimicry between parasites and host antigens could play a substantial role in the pathophysiology of chronic ChD. However, it has 
been difficult to demonstrate a correlation between molecular mimicry and clinical findings in most cases. We will next review the previous studies on "circulating anti-M2 muscarinic acetylcholine receptor antibodies in ChD patients" and discuss their potential physiopathological significance with respect to esophageal and colonic alterations. In particular, we will focus on our own contributions to the field.

\section{ANTI-M2 MUSCARINIC ACETYLCHOLINE RECEPTOR ANTIBODIES IN ChD}

During the early 90 s, a series of studies were conducted to find a link between heart disease and the humoral immune response in $\mathrm{ChD}$ patients. The circulating IgG fraction from T. cruzi-infected mice was found to elicit a negative inotropic effect in isolated mouse atria preparations and trigger biochemical signals classically coupled to M2 muscarinic acetylcholine receptor (M2R) activation in atrium strips from non-infected mice, such as a decrease in cAMP accumulation. This antibody fraction was also able to inhibit the binding of a muscarinic radioligand to murine heart membranes in a non-competitive manner ${ }^{26}$, suggesting a direct interaction between the IgG antibodies and the M2R. Years later, the $\mathrm{IgG}$ fraction of chronic $\mathrm{ChD}$ patients was found to mimic the pharmacologic behavior of that from T. cruzi-infected mouse previously reported ${ }^{27}$. Moreover, the human IgG fraction from $\mathrm{ChD}$ patients not only decreased atrial contractility but also inhibited carbachol-28 and pilocarpine-27,29 mediated negative inotropic effects in a non-competitive manner. For this reason, this antibody fraction was thought to mimic the effect of muscarinic partial agonists. In addition, $\mathrm{ChD}$ IgG was found to inhibit L-type Ca2+ currents on binding to the M2 receptor ${ }^{30}$ and promote short-term regulation of the M2R by inducing desensitization and sequestration of M2R stably expressed in $\mathrm{CHO}$ cells $^{31}$.

The direct interaction of anti-M2R antibodiens from ChD patients with their target receptor was demonstrated by immunoprecipitation $^{28,32}$, immunoblotting ${ }^{28,32}$ and $\frac{\text { a }}{\frac{5}{3}} \mathrm{a}$ combination of both procedures ${ }^{31}$. Moreover, an epitope within the second extracellutar loop (II ECL) of the M2R was identified as the main immunogenic region interacting with the anti-M2R antibody IgG fraction ${ }^{33-35}$. Next, a synthetic peptide with an amino acid quence within the II ECL of the human MäR was used as an immobilized antigen to monitor the immune reactivity of circulating ainti-M2R antibodies by ELISA or affinity purify monospecific anti-M2 $\mathrm{mACh}$ antibodies from the serum IgG fraction ${ }^{33-35}$.

The monospecific anti-II ECL antibody frằction was found to reproduce all the pharmacological effects of the whole IgG fraction ${ }^{33} 35$. In addition, this antibody fraction was able to induce basal bradycardia on murine cardiomyocytes and rat isolated atria ${ }^{34,36}$, confirming the muscarinic response on functional myocardium.

The presence of circulating anti-M2R antibodies was found to be strongly associated with the evidence for cardiovascular dysautonomia in ChD patients with or without ECG alterations. Furthermore, Ribeiro et al. found that the levels of circulating anti-M2R antibodies negatively correlated with HRV index 
power, suggesting an inhibitory effect of anti-M2R antibodies on vagal function ${ }^{37}$. Other authors reported a high prevalence of anti-M2R antibodies in ChD patients with sinus node dysfunction ${ }^{38}$.

\section{ANTI-M2R ANTIBODIES IN CHRONIC ChD PATIENTS WITH ACHALASIA AND MEGACOLON}

Achalasia and megacolon are neurodegenerative disorders primarily not only affecting the myenteric plexus of the ENS but also vagal trunks and dorsal vagal nucleus. Actually, several studies, although not all, have provided evidence that patients with primary achalasia, whose symptoms are fairly similar as compared with those observed in the chagasic form, show functional autonomic nervous system disturbances (vagal impairment $)^{39-42}$. Besides degeneration and decreased numbers of intrinsic myenteric neurons, reduced numbers of intersticial cells of Cajal $^{14,43,44}$ and glial cells ${ }^{14,22,45}$, hypertrophic smooth cells, and increased fibrosis have also been reported, suggesting a complex physiopathology of chagasic esophageal and colonic disorders.

Most studies so far have focused on the integrity of pre- and post-ganglionic innervation, without considering the mechanisms of synaptic transmission at the level of effector tissues. The M2R is widely expressed in gastrointestinal smooth muscle fibers and plays an important role in smooth muscle contractility. Agonist activation of M2R can contribute to smooth muscle contractility either by promoting a direct contractile effect together with the M3 subtype ${ }^{46-49}$ or by counteracting the relaxant effect of ligands that increase cAMP (i.e. noradrenaline) ${ }^{50}$.

The previous studies had shown that (a) an anti-T. cruzi monoclonal antibody that cross-reacts with host antigens, particularly, in esophageal and colonic smooth muscle binds to and activates M2R in vitro ${ }^{51-53}$; (b) anti-M2R anti-

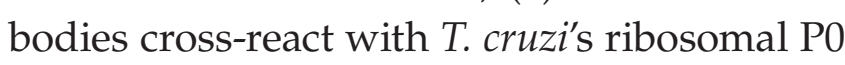
protein, suggesting that these antibodies coû̀ d be generated as a result of an immune response to a T. cruzi ribosomal protein through a molecular mimicry mechanism ${ }^{34}$; and (c) circulating anti-M2R antibodies with agonist-like activity are associated with parasympathetic dysautonomia in chronic $\mathrm{ChD}$ patients $27,35,37$. On the basis of these results, it was hypothesized that anti-M2R antibodies coutd play a physiopathological role in the gastrointestinal motility disorders in chronic ChD patients. We will next summarize the main findings of our previous reports on anti-M2 circulating antibodies in ChD patients wh achalasia a megacolon 54,55 .

\section{ANTI-M2R ANTIBODIES IN CHRONIC ChD PATIENTS WITH ACHALASIA AND MEGACOLON}

In our previous studies ${ }^{54,55}$, a 24-mer peptide with an amino acid sequence corresponding to the II EC of the human M2R (pM2) was used as an immobilized antigen to screen for circulating anti-M2R antibodies in patients with/ without achalasia or megacolon, either primary or secondary to ChD. These antibodies were found highly prevalent in $\mathrm{ChD}$ patients with achalasia $(\mathrm{ChD}+\mathrm{A}+, 84 \%, n=19)$ or megacolon (ChD+M+, 87\%, $n=15)$, compared with $\mathrm{ChD}$ patients without gastrointestinal damage 
(ChD+A-/ChD+M-, 22\%, $n=31)$, non-chagasic patients with idiopathic achalasia (ChD-A+, $28 \%, n=25)$ or megacolon (ChD-M+, $0 \%, n=3)$, or healthy control patients (ChD-A-/ChD-M-, $0 \%, n=40)$.

It was not surprising that a few $\mathrm{ChD}+\mathrm{A}-$ or $\mathrm{ChD}+\mathrm{M}$ - patients showed significant titers of anti-M2R antibodies because these antibodies are frequently found in asymptomatic ChD individuals with dysautonomia ${ }^{27,35,36}$. Besides, it is tempting to speculate that at least some $\mathrm{ChD}$ patients with no motility disorders that were currently seropositive for anti-M2R antibodies might develop achalasia and/or megacolon in the future. Antibody levels were also higher in $\mathrm{ChD}+\mathrm{A}+$ and $\mathrm{ChD}+\mathrm{M}+$ patients than in the other groups. The remarkable differences in immune reactivity and frequency of anti-M2R antibodies between chagasic and idiopathic achalasia/megacolon patients suggest that these antibodies are characteristic of patients with motility disorders secondary to $\mathrm{ChD}$ and do not appear to play a major role in individuals with idiopathic motility disorders.

The serum IgG fractions from $\mathrm{ChD}+\mathrm{A}+$ and $\mathrm{ChD}+\mathrm{M}+$ patients elicited pharmacological effects associated with M2R activation on rat smooth muscle strips. Actually, these antibodies enhanced tonic contractions and promoted inhibition of both basal and isoproterenol-stimulated cAMP accumulation in lower esophageal and distal colonic preparations. Both the tonic contractile effect and the inhibition of cAMP accumulation were inhibited by the muscarinic peptide pM2, a selective M2 muscarinic antagonist AF-DX 116, and the Gi protein inhibitor pertussis toxin, demonstrating theM2 subtype specificity, the involvement of a Gi protein-mediated effect, and the participation of the M2R's II ECL in the effects of anti-M2R antibodies, respectively. The monospecific anti-pM2 antibody fraction from $\mathrm{ChD}+\mathrm{A}+$ and $\mathrm{ChD}+\mathrm{M}+$ patients mimicked the contractile and biochemical effects of the crude IgG preparations, confirming the epitope-specificity of $\operatorname{Ig}_{g}^{\infty} G$ antibodies.

The high frequency of circulating anti-M2̌ R antibodies in patients with either achalasia or megacolon suggests an association between specific serum antibodies and motility disorders in ChD. If so, how can we explain the small fraction of $\mathrm{ChD}+\mathrm{A}+$ or $\mathrm{ChD}+\mathrm{M}+$ with undetectable circulating anti-M2R antibodies? Actually, a previous study showed a frequency of $100 \%$ for anti-M2R antibodies in a population of $30 \mathrm{ChD}+\mathrm{M}+$ patients, by measuring the chronotropic effect of patient's Ig $G$ fraction on cultured rat cardiomyocytes $(n=30)^{56}$. The screening procedure used by these authors has been proved more sensitio than conventional ELISA against an immobilized peptide presumably because antibodies interact with a native receptor and promotè a physiological amplified response. Therefore, the antibody frequency detected in our studies should probably increase if the sensitivity of our detection procedure was enhanced.

As regards the potential association between serum anti-M2R antibodies and the pathophysiology of achalasia, these findings do not explain the degenerative lesions and the loss of myenteric neurons, which are the main alterations in this disorder. However, the agonist-like muscarinic activity could contribute to LES hypertension by enhancing LES tonic contractions through M2R activation. Hence, muscarinic effects of anti-M2R antibodies 
could counteract physiological $\beta$-adrenergic LES relaxation by promoting Gi-mediated inhibition of adenylate cyclase.

Unlike idiopathic megacolon, where the excitatory innervation is preserved, megacolon secondary to $\mathrm{ChD}$ is characterized by a loss of cholinergic excitatory neurons ${ }^{57}$. A decrease in the excitatory activity is believed to be associated with lower basal motility index and wave frequency than in normal subjects. Other alterations, such as rectum-sigmoid motor incoordination and the impairment of RAIR in response to rectal distension, can also be explained by the destruction of the excitatory motor innervation ${ }^{4}$.

The contribution of circulating anti-M2R antibodies to the physiopathology of megacolon secondary to ChD has been discussed ${ }^{55}$. The potential inhibition of ACh-mediated contractile response through $\mathrm{M} 2 \mathrm{R}$ in the colonic smooth muscle by ChD anti-M2R antibodies could be explained as follows: (a) these antibodies, acting as partial muscarinic agonists, not only could certainly display muscarinic agonist-like activity but also inhibit agonist-mediated receptor activation $27,28,35$, and (b) the chronic exposure of M2R to specific anti-receptor antibodies could promote receptor desensitization and internalization, which would result in the attenuation of the subsequent response to $\mathrm{Ach}^{55}$. Indeed, both hypotheses suggest that the presence of circulating antibodies against M2R could ultimately impair the parasympathetic activity at the level of the effector M2R in smooth muscle cells. While awaiting further studies, agonist-like activity of anti-M2R antibodies could still become a factor of concern, in that the generalized activation of $\mathrm{M} 2 \mathrm{R}$ in colonic smooth muscle could disturb the normal synchronized pattern of peristaltic activity.

\section{FUNDING}

These studies were funded by grants from CONICET (PIP 2012-2014 No 0816 and PIP 2015-2017 No 0377), Fundación Roemmện and Universidad de Buenos Aires. C.B. is Âssociate Professor of Medicine (Universidad Favaloro), and J.G. is an Established Researcher from CONICET.

\section{REFERENCES}

1. Bern C, Montgomery SP, Herwaldt BL, et al. Evaluation and treatment of chagas disease in the United States: a systematic review. JAMA. 2007;298:2171-81.

2. Isselbacher EM, Kligerman SJ, Lam KM, Hurtado RM. Case records of the massachusetts general hospital. Case 2-2010. A 47-year-old man with abdominal and flank pain. N Engl J Med. 2010;362:254-62.

3. de Oliveira RB, Troncon LE, Dantas RO, Menghelli UG. Gastrointestinal manifestations of chagas' disease. Am J Gastroenterol. 1998;93:884-9. 을

4. Matsuda NM, Miller SM, Evora PR. The chronic gastrointestinal manifestations of Chagas disease. Clinics (Sao Paulo). 2009;64:1219-24.

5. de Oliveira RB, Rezende Filho J, Dantas RO, Iazigi N. The spectrum of esophageal motor disorders in chagas' disease. Am J Gastroentêerol. 1995;90:1119-24.

6. van Hoeij FB, Bredenoord AJ. Clinical application of esophageal hightresolution manometry in the diagnosis of esophageal motility disorders. J Neurogastroenterol Motil. 2016;22:6-13.

7. Ghosh SK, Pandolfino JE, Rice J, et al. Impaired deglutitive EGJ relaxation in clinical esophageal manometry: a quantitative analysis of 400 patients and 75 controls. Am J Physiol Gastrointest Liver Physiol. 2007;293:G878-85.

8. Pandolfino JE, Kwiatek MA, Nealis T, et al. Achalasia: a new clinically relevant classification by high-resolution manometry. Gastroenterolo2008;135:1526-33.

9. Bansal A, Kahrilas PJ. Has high-resolution manometry changed the apprọach to esophageal motility disorders? Curr Opin Gastroenterol. 2010;26:344 51 .

10. Rohof WO, Salvador R, Annese V, et al. Outcomes of treatment for ackalasia depend on manometric subtype. Gastroenterology. 2013;144:718-250

11. Salvador R, Costantini M, Zaninotto G, et al. The preoperative manometric pattern predicts the outcome of surgical treatment for esophageal achalasia. J Gastrointest Surg. 2010;14:1635-45.

12. Köberle F. Chagas' disease and chagas' syndromes: the pathology of american trypanosomiasis. Adv Parasitol. 1968;6:63-116.

13. Wood JD, Alpers DH, Andrews PL. Fundamentals of neurogastroenterology. Gut. 1999;45 Suppl 2:II6-II16.

14. Iantorno G, Bassotti G, Kogan Z, et al. The enteric nervous system in chagasic and idiopathic megacolon. Am J Surg Pathol. 2007;31:460-8.

15. Meneghelli UG, de Godoy RA, Macedo JF, et al. Basal motility of dilated and non-dilated sigmoid colon and rectum in chagas' disease. Arq Gastroenterol. 1982;19:127-32 
16. Oliveira RB, Meneghelli UG, de Godoy RA, Dantas RO, Padovan W. Abnormalities of interdigestive motility of the small intestine in patients with chagas' disease. Dig Dis Sci. 1983;28:294-9.

17. Cavenaghi S, Felicio OC, Ronchi LS, et al. Prevalence of rectoanal inhibitory reflex in chagasic megacolon. Arq Gastroenterol. 2008;45:128-31.

18. De Giorgio R, Camilleri M. Human enteric neuropathies: morphology and molecular pathology. Neurogastroenterol Motil. 2004;16:515-31.

19. Barbosa AA, Andrade ZA. Identificação do Trypanosoma cruzi nos tecidos extracardíacos de portadores de miocardite crônica chagásica. Rev Soc Bras Med Trop. 1984;17:123-6.

20. Ede CC, Silveira TP, Micheletti AM, Crema E, Adad SJ. Research on Trypanosoma cruzi and analysis of inflammatory infiltrate in esophagus and colon from chronic chagasic patients with and without mega. J Trop Med. 2012;2012:232646.

21. d'Avila Reis D, Lemos EM, Silva GC, et al. Phenotypic characterization of the inflammatory cells in chagasic megaoesophagus. Trans R Soc Trop Med Hyg. 2001;95:177-8.

22. da Silveira AB, Lemos EM, Adad SJ, et al. Megacolon in chagas disease: a study of inflammatory cells, enteric nerves, and glial cells. Hum Pathol. 2007;38:1256-64.

23. Said G, Joskowicz M, Barreira AA, Eisen H. Neuropathy associated with experimental chagas' disease. Ann Neurol. 1985;18:676-83.

24. Hontebeyrie-Joskowicz M, Said G, Milon G, Marchal G, Eisen H. L3T4+ T cells able to mediate parasite-specific delayed-type hypersensitivity play a role in the pathology of experimental chagas' disease. Eur J Immunol. 1987;17:1027-33.

25. Kierszenbaum F. Chagas' disease and the autoimmunity hypothesis. Clin Microbiol Rev. 1999;12:210-23.

26. Sterin-Borda L, Gorelik G, Borda ES. Chagasic igG binding with cardiac muscarinic cholinergic receptors modifies cholinergic-mediated cellular transmembrane signals. Clin Immunol Immunopathol. 1991;61:387-97.

27. Goin JC, Borda E, Leiros CP, Storino R, Sterin-Borda L. Identification of antibodies with muscarinic cholinergic activity in human chagas' disease: pathological implications. J Auton Nerv Syst. 1994;47:45-52.

28. Goin JC, Storino R, Leiros CP, Borda E, Sterin-Borda L. Human chagasic $\mathrm{IgG}$ and muscarinic cholinergic receptor interaction: pharmacological and molecular evidence. Mol Neuropharmacol. 1994;3:189-96.

29. Goin JC, Perez Leiros C, Borda E, Sterin-Borda L. Modification of cholinergic-mediated cellular transmembrane signals by the interaction of human chagasic igG with cardiac muscarinic receptors. Neuroimmunomodulation. 1994;1:284-91.

30. Hernandez CC, Barcellos LC, Gimenez LE, et al. Human chagasic IgGs bind to cardiac muscarinic receptors and impair L-type Ca2+ currents. Cardiovasc Res. 2003;58:55-65.

31. Leiros CP, Sterin-Borda L, Borda ES, Goin JC, Hosey MM. Desensitization and sequestration of human $\mathrm{m} 2$ muscarinic acetylcholine receptors by autoantibodies from patients with chagas' disease. J Biol Chem. 1997;272:12989-93.

32. Sterin-Borda L, Leiros CP, Goin JC, et al. Participation of nitric oxide signaling system in the cardiac muscarinic cholinergic effect of human chagasic IgG. J Mol Cell Cardiol. 1997;29:1851-65.

33. Goin JC, Pérez Leirós C, Borda E, Sterin-Borda L. Interaction of chagasic autoantibodies with the third extracellular domain of the human heart muscarinic receptor. Functional and pathological implications. Medicina (B Aires). 1996;56:699-704.

34. Elies R, Ferrari I, Wallukat G, et al. Structural and functional analysis of the $B$ cell epitopes recognized by anti-receptor autoantibodies in patients with chagas' disease. J Immunol. 1996;157:4203-11.

35. Goin JC, Leiros CP, Borda E, Sterin-Borda L. Interaction of human chagasic igG with the second extracellular loop of the human heart muscarinic acetylcholine receptor: functional and pathological implications. FASEB J. 1997;11:77-83.

36. Goin JC, Borda ES, Auger S, Storino R, Sterin-Borda L. Cardiac M(2) muscarinic cholinoceptor activation by human chagasic autoantibodies: association with bradycardia. Heart. 1999;82:273-8.

37. Ribeiro AL, Giménez LE, Hernández CC, et al. Early occurrence of anti-muscarinic autoantibodies and abnormal vagal modulation in chagas disease. Int J Cardiol. 2007;117:59-63.
38. Ferrari I, Levin MJ, Elizari MV, Rosenbaum MB, Chiale PA. Cholinergic autoantibodies in sinus-node dysfunction. Lancet. 1997;350:262-3.

39. Nguyen NQ, Holloway RH. Recent developments in esophageal motor disorders. Curr Opin Gastroenterol. 2005;21:478-84.

40. Lopes ER, Tafuri WL, Chapadeiro E. Morphological and quantitative studies of the dorsal vagus nerve and hypoglossus nucleous in chronic chagas' disease with and without megaesophagus. Rev Inst Med Trop Sao Paulo. 1969;11:123-9.

41. Ohlsson B, Ekberg O, Sundkvist G. Achalasia: a vagal disease. Scand J Gastroenterol. 2004;39:527-530.

42. Tafuri WL, Maria TA, Lopes ER. Myenteric plexus lesions in the esopha'gus, jejunum and colon of chronic chagasic patients. Electron microscopy stüdy. Rev Inst Med Trop Sao Paulo. 1971;13:76-91.

43. Adad SJ, Silva GB, Jammal AA. The significantly reduced number of interstitial cells of cajal in chagasic megacolon (CM) patients might contribute to the pathophysiology of CM. Virchows Arch. 2012;461:385-92.

44. Alonso Araujo SE, Dumarco RB, Rawet V, et al. Reduced population of interstitial cells of cajal in chagasic megacolon. Hepatogastroenterology. 2012;59:2147-50.

45. Nascimento RD, de Souza Lisboa A, Fujiwara RT, et al. Characterization of enteroglial cells and denervation process in chagasic patients with and without megaesophagus. Hum Pathol. 2010;41:528-34.

46. Griffin MT, Matsui M, Ostrom RS, Ehlert FJ. The guinea pig ileum lacks the direct, high-potency, M(2)-muscarinic, contractile mechanism characteristic of the mouse ileum. Naunyn Schmiedebergs Arch Pharmacol. 2009; 380:327-35.

47. Braverman AS, Miller LS, Vegesna AK, et al. Quantitation of the contractile response mediated by two receptors: M2 and M3 muscarinic receptor-mediated contractions of human gastroesophageal smooth muscle. J Pharmacol Exp Ther. 2009;329:218-24.

48. Vegesna AK, Braverman AS, Miller LS, et al. Comparison of humand porcine gastric clasp and sling fiber contraction by $\mathrm{M} 2$ and M3 muscarinic receptors. Am J Physiol Gastrointest Liver Physiol. 2010;298:G530-4.

49. Tanahashi Y, Waki N, Unno T, et al. Roles of M2 and M3 muscarinic receptors in the generation of rhythmic motor activity in mouse small intestine. Neurogastroenterol Motil. 2013;25:e687-97.

50. Matsui M, Griffin MT, Shehnaz D, Taketo MM, Ehlert FJ. Increased relaxant action of forskolin and isoproterenol against muscarinic agonist-indūced contractions in smooth muscle from M2 receptor knockout mice. J Pharmacol Exp Ther. 2003;305:106-13.

51. Zwirner NW, Malchiodi EL, Chiaramonte MG, Fossati CA. A lytic monoclonal antibody to Trypanosoma cruzi bloodstream trypomastigotes which recognizes an epitope expressed in tissues affected in chagas' disease. Infect Immun. 1994;62:2483-9.

52. Cremaschi G, Zwirner NW, Gorelik G, et al. Modulation of cardiac physiology by an anti-Trypanosoma cruzi monoclonal antibody after interaçion with myocardium. FASEB J. 1995;9:1482-8.

53. Cremaschi G, Fernández MM, Gorelik G, et al. Modulatory effectș on myocardial physiology induced by an anti-Trypanosoma cruzi monoclēnal antibody involve recognition of major antigenic epitopes from beta1-adrenergic and M2-muscarinic cholinergic receptors without requiring receptor cross-linking. J Neuroimmunol. 2004;153:99-107.

54. Goin JC, Sterin-Borda L, Bilder CR, et al. Functional implications of circulating muscarinic cholinergic receptor autoantibodies in chagasic patients with achalasia. Gastroenterology. 1999;117:798-805.

55. Sterin-Borda L, Goin JC, Bilder CR, et al. Interaction of human chagasic IgG with human colon muscarinic acetylcholine receptor: molecular and functional evidence. Gut. 2001;49:699-705.

56. Wallukat G, Muñoz Saravia SG, Haberland A, et al. Distinct patterns of autoantibodies against G-protein-coupled receptors in chagas' cardiomyopathy and megacolon. Their potential impact for early risk assessment in asymptomatic chagas' patients. J Am Coll Cardiol. 2010;55:463-8.

57. Jabari S, de Oliveira EC, Brehmer A, da Silveira AB. Chagasic megacolon: enteric neurons and related structures. Histochem Cell Biol. 2014;142:235-44. 